\title{
INFESTATION BY ENNEOTHRIPS FLAVENS MOULTON AND YIELD OF PEANUT CULTIVARS
}

\author{
Andrea Rocha Almeida de Moraes*; André Luiz Lourenção; Ignácio José de Godoy; Gustavo \\ de Carvalho Teixeira \\ IAC - Centro de Pesquisa e Desenvolvimento de Fitossanidade, C.P. 28 - 13001-970 - Campinas, SP - Brasil. \\ *Corresponding author <andreamoraes@gmail.com>
}

\begin{abstract}
Because of damages caused, general occurrence in crops, and high population levels, the most important peanut pest in Brazil is the thrips Enneothrips flavens Moulton (Thysanoptera: Thripidae). A field experiment was carried out during the 2001/2002 growing season, in Campinas and Pindorama, State of São Paulo, Brazil, to evaluate the influence of $E$. flavens on yield of six peanut cultivars. Treatments comprised three cultivars of the upright type and three of the runner type, with and without chemical control of the insect. Thrips infestation was evaluated by insect countings on young leaflets. Yield and yield reduction percentage due to the lack of thrips control were estimated. The lack of insect control resulted in yield reductions varying from 19.5 to $62.7 \%$, depending on the level of infestation, cultivars, and location. Runner cultivar IAC Caiapo, presented the lowest yield reductions in both locations (19.5 and 28.7\%), even when exposed to thrips infestation for a longer period because of its longer cycle. This fact characterizes 'IAC Caiapo' as resistant to E. flavens.
\end{abstract}

Key words: Arachis hypogaea L., Thysanoptera, Thripidae, insecta, host plant resistance

\section{INFESTAÇÃO DE ENNEOTHRIPS FLAVENS MOULTON E PRODUTIVIDADE DE CULTIVARES DE AMENDOIM}

\begin{abstract}
RESUMO: Em função dos danos causados e ocorrência generalizada na cultura, a praga mais importante do amendoim no Brasil é Enneothrips flavens Moulton (Thysanoptera: Thripidae). Com o objetivo de avaliar a influência do ataque de E. flavens na produtividade de seis cultivares de amendoim, foi implantado um experimento em campo, no ano agrícola 2001/2002, em duas localidades do Estado de São Paulo: Campinas e Pindorama. As cultivares de amendoim avaliadas foram três de porte vegetativo ereto e três rasteiros, com controle e ausência total de controle químico da praga. Para a avaliação da infestação de tripes, foram realizadas amostragens a partir dos 29 dias após o plantio, a cada duas semanas, quando foram coletados 10 folíolos fechados por subparcela. Ao final do ciclo, avaliou-se o peso em casca das parcelas e determinou-se o índice de redução na produção provocado pela ausência de controle do tripes nessas cultivares. A ausência de controle do tripes provocou reduções de produção entre 19,5 a 62,7\%, dependendo do nível de infestação, da cultivar utilizada e do local de plantio. Embora exposto a um maior período de infestação devido a seu ciclo mais longo, 'IAC Caiapó' apresentou a menor perda produtiva quando não houve controle da praga (19,5 a 28,7\%, dependendo da localidade plantada), demonstrando possuir resistência a esse inseto.

Palavras-chave: Arachis hypogaea L., Thysanoptera, Thripidae, insecta, resistência de plantas a insetos
\end{abstract}

\section{INTRODUCTION}

Because of the extent of damages caused, general occurrence in crops, and high population levels, the most important peanut pest in Brazil is the thrips Enneothrips flavens Moulton (Thysanoptera: Thripidae) (Rossetto et al., 1968; Monteiro et al., 1999; Gallo et al., 2002). The species attacks young leaflets on plant shoots, sucking the contents of plant cells and causing deformations and streaking, which reflects as damage in terms of productivity (Gallo et al., 2002). Damage to plants becomes conspicuous after shoots opening, when the leaves show clear deformations, curling, and silvering. The crop is most sensitive to the pest's attack from germination until 50 to 70 days after planting, and the critical period is between 50 and 60 days after germination (Batista et al., 1973). Yield loss up to $1 \%$ can be estimated when detection averages one thrips per closed or semi-closed leaflet, until 70 days after germination, that is, if during the critical period a mean infestation of 10 thrips per leaflet occurs, a $10 \%$ loss in productivity is to be expected (Nakano et al., 1981). Campbell \& Wynne, cited by Stalker \& Campbell (1983), stated that in peanut the presence of one thrips [Frankliniella fusca (Hinds)] per end shoot can damage young leaflets by 33 to $80 \%$.

It is extremely important to know the effects of infestation by this pest on different peanut cultivars. Currently, studies related to E. flavens usually involve only 
chemical products to control populations, without taking into account whether new cultivars developed and released to producers bear or not any level of resistance to the insect. Therefore, in this work, the effect of attack by this thrips species was evaluated on the six most commonly planted peanut cultivars in the State of São Paulo, in the aim to quantify yield losses in these cultivars, with and without chemical control of thrips.

\section{MATERIAL AND METHODS}

A field experiment was replicated at two localities in the State of São Paulo, Brazil: at Campinas

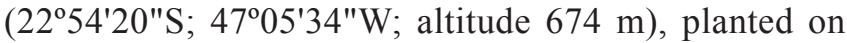
Dec/10/2001, and at Pindorama $\left(21^{\circ} 13^{\prime} \mathrm{S}\right.$; $48^{\circ} 56^{\prime} \mathrm{W}$; altitude $562 \mathrm{~m}$ ), planted on Dec/11/2001. The experiment was organized as split-plots, in a randomized block design $(n=6)$. The plots corresponded to treatments with and without thrips chemical control (treated and untreated plots), while the sub-plots consisted of six peanut cultivars, three with upright growth habit and short cycle (IAC Tatu ST, IAC 5, and IAC 22), and three with runner (spreading) growth habit and long cycle (Runner IAC 886, Tegua, and IAC Caiapo).

In plots receiving chemical treatments, seeds were treated before planting with $100 \mathrm{~g}$ of thiamethoxam per $100 \mathrm{~kg}$ seeds. Starting at 40 days after planting, plots were sprayed with $100 \mathrm{~g} \mathrm{ha}^{-1}$ thiamethoxam formulated as a water-dispersible granulate, six times in Campinas and five times in Pindorama, every two weeks.

Each seedbed (subplot) consisted of four 10-m long rows of each cultivar, 150 seeds were sown per row. Rows were spaced $90 \mathrm{~cm}$ for runner cultivars and $60 \mathrm{~cm}$ for the upright types. Thinning was performed after plants emerged, leaving 10 plants per meter in runner type cultivars, and 13 plants per meter in upright cultivars.

Fertilization and liming were applied according to soil analyses and technical recommendations for the crop (Raij et al., 1997). Other management practices included weed control by hoeing whenever necessary, and applications of difenoconazole to control diseases.

At both localities, thrips samples were collected at 29 DAP and then at every 15 days. Ten apical shoots at the stage of unopened leaflet were randomly sampled per subplot. Samples were placed in semipermeable plastic bags and stored in a cold chamber, at $12^{\circ} \mathrm{C}$, for temporary preservation. For thrips counting, each properlyidentified sample was removed from cold storage and placed in a Petri dish. A single closed leaflet was taken from each shoot, and evaluated under a stereoscopic microcope. Considering the variation in size between the four leaflets, the most developed was taken. The leaflet was placed under the microscope and there opened with a tweezer; the total number of thrips, as well as the numbers of nymphs, live adults, and dead adults were recorded.
Sprayed plants were harvested at maturation. In the untreated plots, harvesting time was defined by the visual aspect of the plants, as related to insect damage. Damaged plants tend to be less developed, and antecipate their point of maturation. In Campinas, 'IAC Tatu ST' was harvested on $03 / 26$, 'IAC 5' and IAC 22 on 04/01, 'Runner IAC 886' and 'Tegua' on 04/15, and 'IAC Caiapo' on 04/24/2002. In Pindorama, 'IAC Tatu ST' was harvested on $03 / 20$, 'IAC 5 ' and 'IAC 22 ' on $03 / 26$, 'Runner IAC 886' and 'Tegua' on $04 / 03$, and 'IAC Caiapo' on 04/05/2002.

After pulling out the plants, the pods were removed from the vines, and dried in the sun. Next, the yield of unshelled peanuts was determined for each subplot, and the weight of 100 randomly chosen kernels was also recorded; the kernels were obtained by shelling 500 g samples of pods. The results obtained were submitted to an exploratory analysis of variance using the SAS software. Since assumptions for analysis of variance were not met, nonparametric analyses were performed using the Friedman test to compare cultivars, and the multiple comparison, Wilcoxon test $(P<0.05)$, to compare treatments, through the BioEstat 3.0 Statistical Software.

\section{RESULTS AND DISCUSSION}

At both locations, the number of thrips per leaflet in plots treated with thiamethoxam was maintained at levels below 1.0 for all cultivars during the entire crop cycle, indicating that thiamethoxam was effective to control the insect. In Campinas, the mean number of thrips per leaflet in untreated plots peaked at 56 DAP (Figure 1). Cultivar IAC 5 showed the highest infestation among all cultivars tested. A second, lower-intensity peak was observed at 85 DAP for 'IAC Tatu ST' and 'IAC 5'. Similar fluctuations in populations of $E$. flavens in peanut were observed by Castro et al. (1972). Those authors associated population densities of the insect to the phenology of the peanut plants, since thrips infestation increased as plants produced more shoots and young leaflets; on the other hand, as the emission of young leaflets decreased, the infestation by thrips also decreased. In the present study, the presence of a second peak of the thrips population could be explained by the raising of a new generation of the insect.

In Pindorama, high infestations of thrips occurred as early as 29 DAP (Figure 1), possibly because the experiment was located next to commercial peanut-producing areas and, therefore, a higher number of host neighboring plants were present favored early infestation. A second infestation peak ocurred at 57 DAP.

In both Campinas and Pindorama, thrips populations declined from 85 DAP down to the end of the crop cycle, because such older plants do not produce young leaflets over which insects can reproduce and feed (Castro 

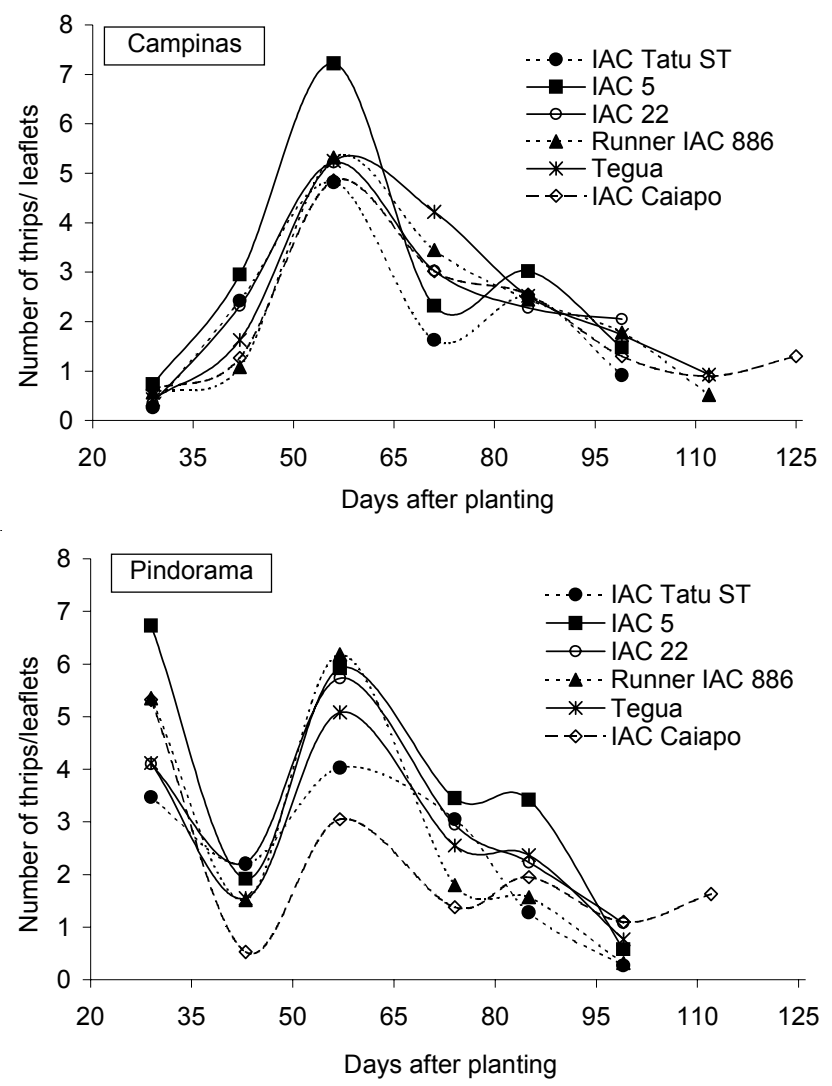

Figure 1 - Number of $E$. flavens per leaflet in six peanut cultivars without chemical treatment, during the plants' development cycle. Campinas and Pindorama, SP, Brazil, 2001/2002. et al., 1972). In untreated plots at both locations, cultivar IAC 5 showed the highest thrips infestation throughout the crop cycle. The lowest infestation was found on cultivar IAC Caiapo in Pindorama, and on IAC Tatu ST in Campinas. Gabriel et al. (1996; 1998) studied the fluctuation of $E$. flavens populations in seven peanut cultivars and also found differences in the mean number of thrips per leaflet among cultivars.

The differences in weight of 100 kernels observed among the cultivars in treated plots are due to their varietal characteristics (Godoy et al., 1999). In Pindorama, the absence of thrips control affected the mean kernel weight of the cultivars, except for IAC 22 and IAC Caiapo. In Campinas, this effect was not observed. The significantly higher values of the untreated plots in IAC 5 and Runner IAC 886 can be explained by a compensation mechanism through which peanut plants under stress tend to yield lower number of pods, and so, concentrate their energy to fill the remaining pods, resulting in slightly heavier kernels. The tendency of signicant effects of thrips on kernel weight in Pindorama as compared to Campinas could be explained by the pattern of insect infestation in that location, since it occurred earlier (29 DAP) and presented a second peak at 57 DAP, thus affecting plants more severely.

Yield was affected by the absence of thrips control in all cultivars, at both localities (Table 1). In Campinas, when thrips were controlled, yield means ranged between 4,191 $\mathrm{kg} \mathrm{ha}^{-1}$ ('IAC Caiapo') and 3,750

Table 1 - Weight of 100 kernels, yield, and yield reduction index in six peanut cultivars, under natural infestation by $E$. flavens, in insecticide treated and untreated plots, under field conditions. Campinas and Pindorama, SP, Brazil, 2001/2002.

\begin{tabular}{|c|c|c|c|c|c|c|c|c|c|c|}
\hline \multirow{2}{*}{ Cultivar } & \multicolumn{4}{|c|}{100 -kernel weight ${ }^{1}$} & \multicolumn{4}{|c|}{ Yield reduction index ${ }^{1}$} & \multicolumn{2}{|c|}{ Yield reduction index ${ }^{1}$} \\
\hline & treated & rank & untreated & rank & treated & rank & untreated & rank & & rank \\
\hline & g & & g & & $\%$ & & $\%$ & & $\%$ & \\
\hline \multicolumn{11}{|c|}{ Campinas } \\
\hline IAC Tatu ST & $40.1 \mathrm{c} \mathrm{A}$ & 1.00 & $40.7 \mathrm{~b} \mathrm{~A}$ & 1.00 & 3917 a $\mathrm{A}$ & 3.17 & $2792 \mathrm{ab} \mathrm{B}$ & 1.00 & $28.7 \mathrm{ab}$ & 3.00 \\
\hline IAC 5 & $55.1 \mathrm{bc} \mathrm{B}$ & 2.08 & $58.2 \mathrm{ab} \mathrm{A}$ & 3.50 & 3750 a $\mathrm{A}$ & 2.33 & $2725 \mathrm{ab} B$ & 3.50 & $27.3 \mathrm{ab}$ & 3.17 \\
\hline IAC 22 & $57.2 \mathrm{abc} \mathrm{A}$ & 3.75 & $57.2 \mathrm{ab} \mathrm{A}$ & 2.50 & 4142 a $\mathrm{A}$ & 3.67 & $2859 \mathrm{ab} \mathrm{B}$ & 2.50 & $30.9 \mathrm{ab}$ & 3.33 \\
\hline Runner IAC 886 & $57.6 \mathrm{abc} B$ & 3.83 & 59.7 a $\mathrm{A}$ & 5.00 & 3988 a $\mathrm{A}$ & 3.17 & $2866 \mathrm{ab} \mathrm{B}$ & 5.00 & $28.1 \mathrm{ab}$ & 3.50 \\
\hline Tegua & 59.6 a A & 5.50 & $59.2 \mathrm{a} \mathrm{A}$ & 4.33 & 3971 a $\mathrm{A}$ & 3.67 & 2436 b B & 4.33 & $38.7 \mathrm{a}$ & 5.50 \\
\hline IAC Caiapo & $58.9 \mathrm{ab} \mathrm{A}$ & 4.83 & 58.7 a $\mathrm{A}$ & 4.67 & 4191 a $\mathrm{A}$ & 5.00 & 3375 a $\mathrm{B}$ & 4.67 & $19.5 \mathrm{~b}$ & 2.50 \\
\hline \multicolumn{11}{|c|}{ Pindorama } \\
\hline IAC Tatu ST & $29.2 \mathrm{~b} \mathrm{~A}$ & 1.00 & $26.7 \mathrm{~b} \mathrm{~B}$ & 1.00 & $2830 \mathrm{~b} \mathrm{~A}$ & 1.50 & $2000 \mathrm{ab} \mathrm{B}$ & 4.17 & $29.3 \mathrm{bc}$ & 2.50 \\
\hline IAC 5 & $45.2 \mathrm{ab} \mathrm{A}$ & 2.67 & $40.1 \mathrm{~b} \mathrm{~B}$ & 2.67 & $3243 \mathrm{ab} \mathrm{A}$ & 3.50 & $1563 \mathrm{ab} B$ & 3.33 & $51.8 \mathrm{ab}$ & 3.67 \\
\hline IAC 22 & $44.7 \mathrm{ab} \mathrm{A}$ & 2.50 & $43.1 \mathrm{ab} \mathrm{A}$ & 4.00 & $3334 \mathrm{ab} A$ & 2.83 & $1997 \mathrm{ab} B$ & 4.00 & $40.1 \mathrm{bc}$ & 2.33 \\
\hline Runner IAC 886 & 53.7 a A & 5.17 & $40.8 \mathrm{ab} \mathrm{B}$ & 3.50 & 3739 a $\mathrm{A}$ & 5.00 & 1392 b B & 1.83 & $62.7 \mathrm{a}$ & 5.33 \\
\hline Tegua & 51.2 a A & 4.83 & $42.0 \mathrm{ab} \mathrm{B}$ & 3.83 & $3319 \mathrm{ab} A$ & 3.33 & 1394 b B & 1.83 & $58.0 \mathrm{a}$ & 5.17 \\
\hline IAC Caiapo & 50.0 a $\mathrm{A}$ & 4.83 & 49.3 a A & 6.00 & 3853 a A & 4.83 & 2747 a B & 5.83 & $28.7 \mathrm{c}$ & 2.00 \\
\hline
\end{tabular}

${ }^{1}$ Median followed by the same upper case letters in the row (between treatments) by Wilcoxon and lower case letters in the column (between cultivars) are not different at the significance level by Friedman nonparametric test and multiple comparisons $(P<0.05)$. 
$\mathrm{kg} \mathrm{ha}^{-1}$ ('IAC 5'). In untreated plots, 'IAC Caiapo' showed the highest value, with $3,375 \mathrm{~kg} \mathrm{ha}^{-1}$, while the smallest mean was obtained by cultivar Tegua, at 2,436 $\mathrm{kg} \mathrm{ha}^{-1}$. In Pindorama, cultivars IAC Caiapo and Runner IAC 886 were more productive when treated, differing from 'IAC Tatu ST'. Under these conditions, yield means varied between $3,853 \mathrm{~kg} \mathrm{ha}^{-1}$ ('IAC Caiapo') and 2,830 $\mathrm{kg} \mathrm{ha}^{-1}$ ('IAC Tatu ST'). In untreated plots, 'IAC Caiapo' was also the most productive, differing from the other two runner cultivars, Runner IAC 886 and Tegua. In the absence of control, as occurred in Campinas, 'IAC Caiapo' was the most productive, yielding $2,747 \mathrm{~kg} \mathrm{ha}^{-1}$; the lowest yield $\left(1,392 \mathrm{~kg} \mathrm{ha}^{-1}\right)$ was observed in cultivar Runner IAC 886 . These data ratify papers by Calcagnolo et al. (1974a; 1974b), who reported that attack by E. flavens in peanut crops grown in the rainy and drought periods causes yield reductions of 39.2 and $22.9 \%$, respectively, and confirm the importance of this insect as a pest in peanut.

The lack of control of $E$. flavens in peanut caused yield reductions between 19.5 and $62.7 \%$, depending on the level of infestation by the insect, cultivar, and planting location. Considering the yield reduction index resulting from the comparison between treated and untreated plots, which is used to quantify yield loss caused by thrips infestations, reductions were lower in Campinas (between 19.5 and 38.7\%), and higher in Pindorama (between 28.7 and $62.7 \%$ ) (Table 1). According to this index, cultivar IAC Caiapo was the least affected by the pest, showing the smallest reduction index in both locations: Campinas 19.5\%, and Pindorama 28.7\%. In Campinas, 'IAC Caiapo' differed from cultivar Tegua, which showed the highest reduction (38.7\%), while in Pindorama 'IAC Caiapo' differed from 'Runner IAC 886', 'Tegua', and 'IAC 5', which showed the greatest reductions: 62.7, 58.0, and $51.8 \%$, respectively. The yield reduction in 'IAC 5' was relatively low in Campinas, although it showed the highest number of thrips per leaflet. In fact, the three early maturing cultivars, IAC 5, IAC 22 and IAC Tatu ST, tended to be less affected in yield due to the insect infestation, as compared to the long-cycle runner cultivars Tegua and Runner IAC 886. In this case, it can be suggested that the shorter cycle enables peanut plants to a certain escape from the pest effects.

The long-cycle cultivar IAC Caiapo, even exposed to thrips infestation for a longer period in the field, withstands the pest attack, resulting in a smaller yield reduction. This fact characterizes 'IAC Caiapo' as bearing resistance to E. flavens. Since in Campinas this cultivar did not present lower thrips density in relation to the others, and yet showed the lowest yield reduction, it can be suggested that a tolerance mechanism could also be involved, to explain the field performance of this cultivar. Depending on the cultivar, the yield reduction indices may be higher or lower, so that selecting a cultivar with resistance against the insect, such as 'IAC Caiapo', can be considered an important factor for the success of peanut crops, especially when reducing costs of production become crucial.

\section{ACKNOWLEDGEMENTS}

To Renata C. Monteiro, Ph.D., for identifying the thrips species, to Coordenação de Aperfeiçoamento de Pessoal de Nível Superior (CAPES) for granting a Master's scholarship to the first author, and to Conselho Nacional de Desenvolvimento Científico e Tecnológico (CNPq) for granting scientific productivity scholarships to the second and third authors.

\section{REFERENCES}

BATISTA, G.C.; GALLO D.; CARVALHO, R.P.L. Determinação do período crítico de ataque do tripes do amendoim, Enneothrips flavens Moulton, 1941, em cultura “das águas”. Anais da Sociedade Entomológica do Brasil, v.2, p.45-53, 1973.

CALCAGNOLO, G.; LEITE, F.M.; GALLO, J.R. Efeitos da infestação do tripes nos folíolos do amendoinzeiro Enneothrips (Enneothripiella) flavens Moulton, 1941, no desenvolvimento das plantas, na qualidade da produção de uma cultura "da seca". O Biológico, v.40, p.239-240, $1974 \mathrm{a}$.

CALCAGNOLO, G.; LEITE, F.M.; GALLO, J.R. Efeitos da infestação do tripes nos folíolos do amendoinzeiro Enneothrips (Enneothripiella) flavens Moulton, 1941, no desenvolvimento das plantas, na qualidade da produção de uma cultura "das águas”. O Biológico, v.40, p.241-242, $1974 b$.

CASTRO, P.R.C.; PITELLI, R.A.; PASSILONGO, R.L. Variações na ocorrência de algumas pragas do amendoinzeiro relacionadas com o desenvolvimento da cultura. Anais da Sociedade Entomológica do Brasil, v.1, p.5-15, 1972.

GABRIEL, D.; NOVO, J.P.S.; GODOY, I.J.; BARBOZA, J.P. Flutuação populacional de Enneothrips flavens Moulton em cultivares de amendoim. Bragantia, v.55, p.253-257, 1996.

GABRIEL, D.; NOVO, J.P.S.; GODOY, I.J. Efeito do controle químico na população de Enneothrips flavens Moulton e na produtividade de cultivares de amendoim Arachis hipogaea L. O Biológico, v.65, p.51$56,1998$.

GALLO, D.; NAKANO, O.; SILVEIRA NETO, S.; CARVALHO, R.P.L.; BATISTA, G.C.; BERTI FILHO, E.; PARRA, J.R.P.; ZUCCHI, R.A.; ALVES, S.B.; VENDRAMIN, J.D.; MARCHINI, L.C.; LOPES, J.R.S.; OMOTO, C. Entomologia agrícola. Piracicaba: FEALQ, 2002. 920p.

GODOY, I.J.; MORAES, S.A.; ZANOTTO, M.; SANTOS, R.C. Melhoramento do amendoim. In: BORÉM, A. (Ed.) Melhoramento de espécies cultivadas. 1.ed. Viçosa: UFV, 1999. v.1, p.51-94.

MONTEIRO, R.C.; MOUND, L.A.; ZUCCHI, R.A. Thrips (Thysanoptera) as pests of plant production in Brazil. Revista Brasileira de Entomologia, v.43, p.163-177, 1999.

NAKANO, O.; SILVEIRA NETO, S.; ZUCCHI, R.A. Entomologia econômica. São Paulo: Editora Agronômica Ceres, 1981. 314p.

RAIJ, B.; CANTARELlA, H.; QUAGGIO, J.A.; FURLANI, A.M.C. Recomendações de adubação e calagem para o estado de São Paulo. Campinas: Instituto Agronômico; Fundação IAC, 1997. 285p. (Boletim Técnico, 100).

ROSSETTO, C.J.; POMPEU, A.S.; TELLA, R. Enneothrips flavens Moulton (Thysanoptera, Thripidae) causando prateamento do amendoinzeiro no Estado de São Paulo. Ciência e Cultura, v.20, p.257, 1968.

STALKER, H.T.; CAMPBELL, W.V. Resistance of wild species of peanut to an insect complex. Peanut Science, v.10, p.30-33, 1983.

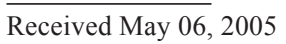

Accepted August 26, 2005 